\title{
Rectal stenosis in pigs associated with Salmonella Typhimurium and porcine circovirus type 2 (PCV2) infection ${ }^{1}$
}

\author{
Tatiane Terumi Negrão Watanabe ${ }^{2}$, Priscila Zlotowski ${ }^{2}$, Luiz Gustavo Schneider \\ de Oliveira², Verônica Machado Rolim², Marcos José Pereira Gomes ${ }^{3}$, \\ Gustavo Snel ${ }^{3}$ and David Driemeier ${ }^{2^{*}}$
}

\begin{abstract}
Watanabe T.T.N., Zlotowski P., Oliveira L.G.S., Rolim V.R., Juffo G.D., Gomes M.J.P., Snel G. \& Driemeier D. 2011. Rectal stenosis in pigs associated with Salmonella Typhimurium and porcine circovirus type 2 (PCV2) infection. Pesquisa Veterinária Brasileira 31(6):511-515. Setor de Patologia Veterinária, Faculdade de Veterinária, Universidade Federal do Rio Grande do Sul, Av. Bento Gonçalves 9090, Porto Alegre, RS 91540-000, Brazil. E-mail: davetpat@ufrgs.br

Rectal stricture is an acquired annular fibrous constriction of the rectum that results from a variety of chronic necrotizing enteric diseases. In pigs, it is in most cases a sequel of Salmonella infection. Porcine circovirus type 2 (PCV2) is a known pathogen causing immunosuppression in pigs worldwide. PCV2 infected pigs may be predisposed to salmonellosis. In this report, rectal stenosis was observed in 160 pigs from a herd that experienced an outbreak of enteric salmonellosis over a 4-month period. Distension of the abdominal wall and diarrhea were the main clinical signs observed. Five animals were analyzed showing annular cicatrization of the rectal wall $5.0-7.0 \mathrm{~cm}$ anterior to the anorectal junction and Salmonella-positive immunostaining in the large intestine. Salmonella Typhimurium was isolated from fragments of the large intestine. Porcine circovirus type 2 antigen was observed in the mesenteric lymph-node in 4 pigs and in the large intestine in 3 pigs.
\end{abstract}

INDEX TERMS: Rectal stenosis, pigs, Salmonella, PCV2.

\begin{abstract}
RESUMO.- [Estenose retal em suínos associada à enterite causada por Salmonella Typhimurium em animais infectados pelo circovírus suíno tipo 2 (PCV2).] Estenose retal é uma constrição anular fibrosa do reto que pode ser decorrente de qualquer doença entérica crônica necrotizante. Em suínos, é em muitos casos uma seqüela de infecção por Salmonella. Circovírus suíno tipo 2 é um patógeno bem conhecido que causa imunodepressão em suínos e apresenta distribuição mundial. No presente trabalho, estenose retal foi observada em 160 suínos em um rebanho que teve um surto de salmonelose entérica durante 4 meses. Distensão da parede abdominal e diarreia fo-
\end{abstract}

\footnotetext{
${ }^{1}$ Received on January 5, 2011.

Accepted for publication on February 22, 2011.

2 Departamento de Patologia Clínica Veterinária, Faculdade de Veterinária, Universidade Federal do Rio Grande do Sul (UFRGS), Av. Bento Gonçalves 9090, Porto Alegre, RS 95320-000, Brazil. ${ }^{*}$ Corresponding author: davetpat@ ufrgs.br

${ }^{3}$ Laboratório de Bacteriologia Clínica e Veterinária, UFRGS, Porto Alegre, RS.
}

ram os principais sinais clínicos observados. Foram analisados cinco suínos que demonstraram cicatrização anular da parede do reto 5,0 a 7,0 cm anterior a junção anoretal e imuno-histoquímica positiva para Salmonella spp. no intestino grosso. Antígeno de Circovírus suíno tipo 2 foi observado no linfonodo mesentérico de quatro suínos e no intestino grosso de três.

TERMOS DE INDEXAÇÃO: Estenose retal, suínos, Salmonella, PCV2.

\section{INTRODUCTION}

Swine are an important reservoir of Salmonella and many serotypes of these bacteria have been isolated from them (Griffith et al. 2006, Brown et al. 2007, Gelberg 2007, Kich, 2007). Clinical disease is mainly associated with Salmonella Choleraesuis (S. Cholerasuis) and Salmonella Typhimurium (S. Typhimurium) (Schauser et al. 2004, Griffith et al. 2006, Brown et al. 2007, Kich 2007). Transmission can occur by contamination of feed, water or the surroundings where the organism can be ingested or inhaled. Stressor factors such 
as transportation, starvation and concurrent diseases (Lillie et al. 1973, Gelberg 2007, Griffith et al. 2006, Brown et al. 2007, Kich 2007) increase Salmonella shedding by carrier pigs and the susceptibility of exposed pigs.

$S$. Typhimurium is the second most commonly isolated serotype from diseased swine (Griffith 2006, Brown et al. 2007), and is usually associated with enterocolitis. S. Typhimurium enterocolitis normally occurs as a sequel to other enteric or debilitating diseases or in immunologically naïve populations (Ha et al. 2005, Griffith et al. 2006).

Porcine rectal stricture is more common in piglets (Lillie et al. 1973, Wilcock \& Olander 1977a, Perfumo et al. 2002, Griffith et al. 2006, Brown et al. 2007) in most cases as a sequel to Salmonella infection, mainly S. Typhimurium (Wilcock \& Olander 1977b, Seol et al. 2001, Brown et al. 2007), causing fibronecrotic ulcerative proctitis and colitis (Perfumo et al. 2002, Griffith et al. 2006, Brown et al. 2007). Rectal stricture is also reported to be caused by mycotoxicosis, mainly zearalenone, mycotic enteritis, chamydial proctitis, insult from toxic compounds in the feed and genetic predisposition (Lillie et al. 1973, Wilcock. \& Olander 1977a, Seol et al. 2001, Santos et al. 2009) and in all cases the rectal bloody supply is affected. Clinically, it is characterized by distention of the abdomen, caused by gas accumulation and a large volume of feces, appetite loss, emaciation and poor growth (Lillie et al. 1973, Wilcock \& Olander 1977a, Perfumo et al. 2002, Brown et al. 2007, Gelberg 2007).

Porcine cirvovirus type 2 (PCV2) is a pathogen known to cause immunosuppression in pigs (Segalés et al. 2004, $\mathrm{Ha}$ et al. 2005) worldwide. The association of PCV2, S. Choleraesuis and $\mathrm{S}$. Typhimurium has been previously reported to cause a severe outbreak of diarrhea (Ha et al. 2005) in pigs, suggesting an increase in enteric Salmonellosis in pigs infected with PCV2. Also, there is an increase in the number of carriers in the herd and the risk of carcass contamination at slaughter (Schwarz et al. 2010).

The aim of this study is to report five cases of porcine salmonellosis with rectal stricture associated with PCV2 co-infection through clinical and histological features, bacterial isolation, strain characterization and immunohistochemical studies.

\section{MATERIALS AND METHODS}

The pigs investigated in this study belonged to a commercial farrow-to-finish herd in southern Brazil, with 3,800 swine, not vaccinated against PCV2, which had suffered a previous episode of Salmonella infection, with diarrhea and abdo-minal distention affecting animals eighty to one hundred days old.

Fragments of several tissues from 5 pigs eighty to one hundred and twenty days old, showing abdominal distention, were submitted to the Laboratory of Veterinary Pathology at Federal University of Rio Grande do Sul (UFRGS) for diagnostic purposes. Samples were fixed in 10\% phosphate-buffered formalin solution, embedded in paraffin wax, cut into $3 \mu \mathrm{m}$-thick sections, and stained with hematoxylin and eosin (HE). WarthinStarry staining of intestinal samples was performed for the detection of enteric microorganisms.
Immunohistochemical (IHC) studies were performed on the large and small intestine, for detection of Salmonella and porcine circovirus type 2 (PCV2), using the polyclonal antibody antiPCV2 (Sorden et al. 1999, dilution 1:1000) and anti Salmonella (Schauser et al. 2004, Biogenesis $₫$ dilution 1:1000) with $0.05 \%$ protease XIV Sigma® for 15 minutes for antigen retrieval, as well as a modified avidin-biotin peroxidase complex method using diaminobenzidine (Dako®, Carpinteria, CA) as the chromogen.

Intestinal samples were collected and sent to the Laboratory of Veterinary Bacteriology at UFRGS. Attempts to isolate the agent were conducted by both direct plating and selective sample enrichment [modified ISO 6579 protocol]. Briefly, $1 \mathrm{~g}$ of each sample was homogenized in $10 \mathrm{ml}$ of Buffered Peptone Water and incubated at $37^{\circ} \mathrm{C}$. After overnight incubation $100 \mu \mathrm{l}$ aliquots were transferred to tubes containing $10 \mathrm{ml}$ of RappaportVassiliadis Salmonella enrichment broth (Accumedia Manufactures Inc. Lansing, Michigan, USA) and incubated at $42^{\circ} \mathrm{C}$ for $16-20$ hours. Subcultures from the enrichment broths were plated on Rambach agar and incubated at $37^{\circ} \mathrm{C}$ for 24 hours. Suspected colonies were isolated and identified through traditional biochemical reactions, agglutination with Polyvalent Salmonella O antisera (Difco, Detroit, Michigan) and API 20E strips (bioMérieux Inc., Durham, NC, USA). Antimicrobial

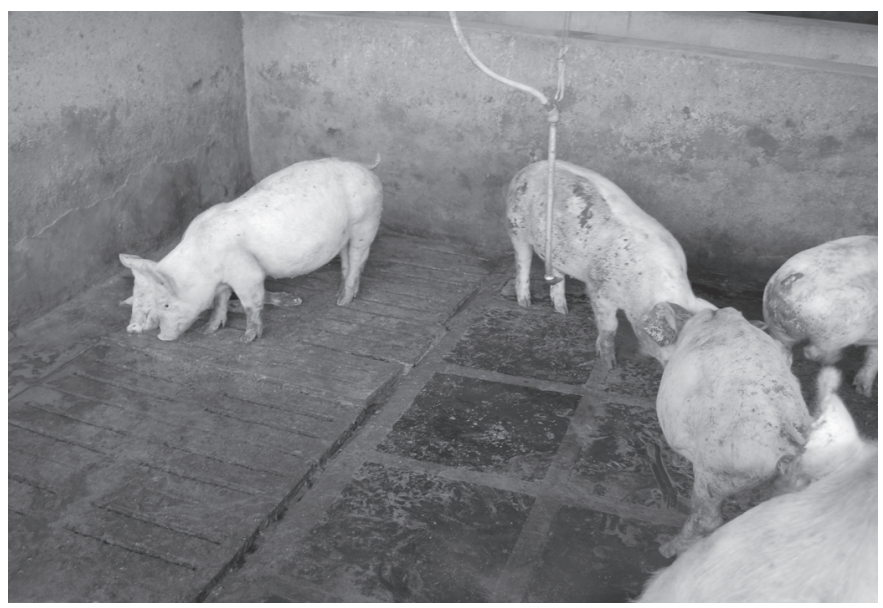

Fig.1. Accentuated abdominal distension in swine.

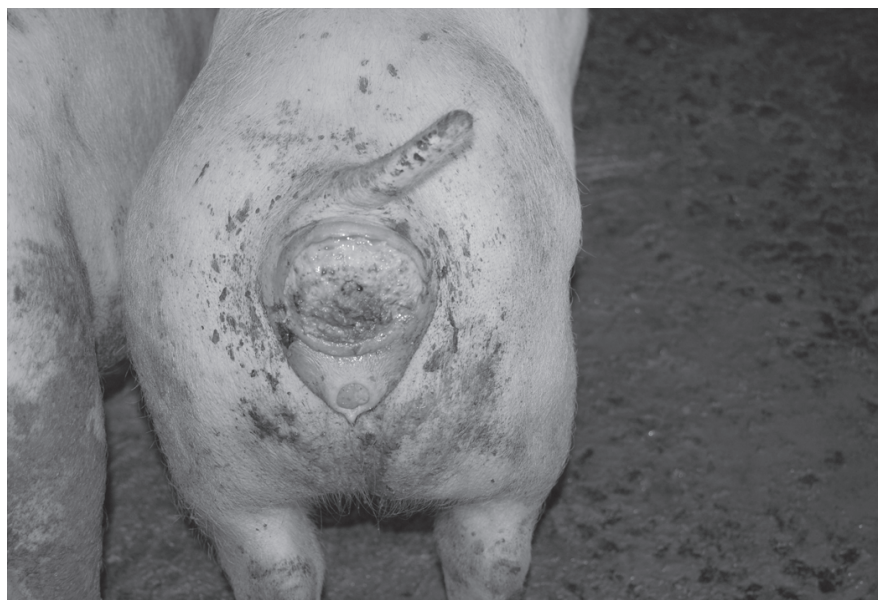

Fig.2. Prolapse and accentuated necrosis of the rectal mucosa in swine. 
resistance was performed in the isolates using the disc diffusion test. The bacterial cultures were then submitted to the Oswaldo Cruz Institute, Rio de Janeiro state, for strain characterization.

Feed samples were sent to the Laboratory of Mycotoxicological analysis at Santa Maria Federal University (UFSM), to determine the presence of mycotoxins.

\section{RESULTS}

The main clinical signs observed in the pigs under study were a marked and progressive distension of the abdomen (Fig.1) for 4-5 days followed by death. Clinical signs were observed over a 4-month period, and rectal stricture occurred in 160 pigs. Furthermore, diarrhea and rectal prolapse (Fig.2) were observed in some pigs from the same facility. Analysis of the water pipe during this outbreak showed Salmonella spp. contamination.

Macroscopically, there was annular stricture of the rectal wall, which was hardened and thickened by fibrous tissue, $5.0-7.0 \mathrm{~cm}$ anterior to the anorectal junction with severe ulceration in the mucosal surface covered by a friable yellowish-greenish membrane (Fig.3).

The main histological findings were observed in the rectum with necrosis and fibrin deposition on the mucosal surface with accentuated and diffuse suppurative infiltrate in the mucosa, submucosa and muscular layers (Fig.4). Thrombosis in the small arterioles of the large intestine mucosa was observed in one case. Degeneration in the small arterioles of the large intestine was observed in 4 cases. In one case multifocal areas of mineralization were observed in the rectal muscular layer. Moderated lymphoid depletion in Peyer's patches and lymphohistiocytic infiltrate was observed in the small intestine in 4 cases (in one case, the small intestine was not submitted). In the mesenteric lymph nodes moderated lymphoid depletion and lymphohistiocytic infiltrate were also observed. In the spleen of one pig accentuated lympho-histiocytic infiltration with giant cells was noted. Balantidium sp., a protozoan usually found in areas of mucosal necrosis due to S. Typhimurium
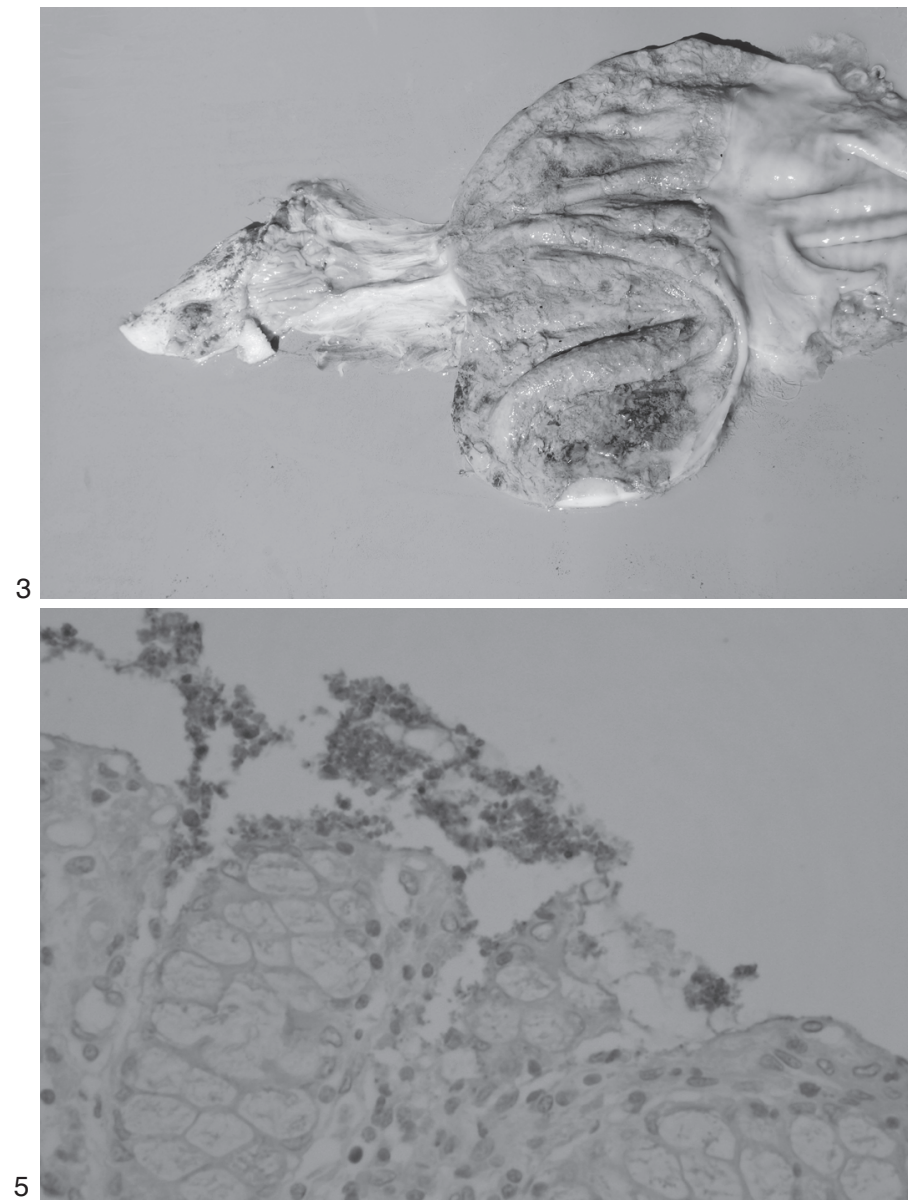

Fig.3. Rectal stenosis with accentuated necrosis of the mucosa and rectal dilatation in swine.

Fig.5. Salmonella-positive immunostaining in necrotic debris in the mucosal surface of the large intestine in swine. Polyclonal antibody. Immunohistochemistry, obj.40x.

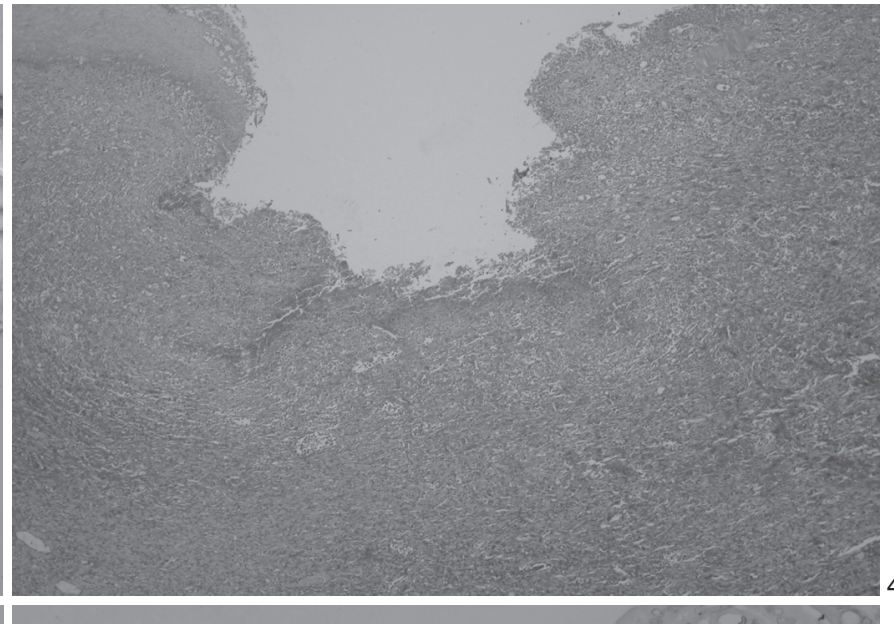

4

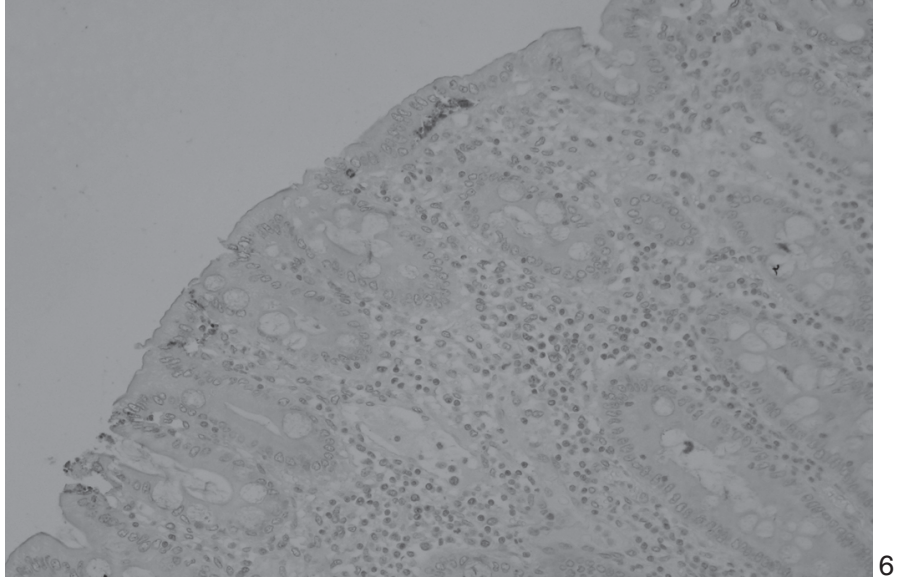

Fig.4. Necrosis and fibrin deposition on the mucosal surface with accentuated and diffuse suppurative infiltrate in the mucosa and submucosa layers of the rectal mucosa in swine. HE, obj.10x.

Fig.6. Salmonella-positive immunostaining in the subepithelial location of the large intestine in swine. Polyclonal antibody. Immunohistochemistry, obj.20x. 
infection (Griffith et al. 2006), was present in the necrotized mucosa of the large intestine in one case.

Immunohistochemically, a strong positive staining was observed for Salmonella spp. on the intestinal mucosal surface of the large intestine, in enterocytes and in macrophages within the intestinal submucosa in all cases tested (Fig.5 and 6). In addition, positive results for PCV2 were observed in the histiocytes of Peyer's patches in the ileum in 4 cases and in the large intestine in 3 cases.

There was no evidence of positive staining using the Warthin-Starry method for Lawsonia intracellularis or Brachyspira sp. In the bacteriological examination of intestinal samples, Salmonella spp. were isolated in pure cultures and the strains were characterized as being $S$. Typhimurium. Salmonella spp. sample isolated showed sensitivity to enrofloxacin, polimixin B, gentamicin, cephalexin and chloramphenicol. Resistance to ampicilin, sulpha and trimethoprim, tetracycline, lyncosamide+ spiramycin, valnemulin and tiamulin were observed. Mycotoxins were not found in the feed samples.

Prior to the occurrence of this outbreak there had been no PCV2 vaccination of the herd, but afterwards a systematic anti PCV-2 vaccination program was implemented.

\section{DISCUSSION}

The definitive diagnosis of rectal stricture associated with porcine salmonellosis with PCV2 co-infection was carried out based on clinical signs, and gross and histopathological features associated with the immunohistochemistry results and microbiological examination.

Rectal stricture is a residual lesion in the rectum of an animal suffering from ulcerative proctocolitis due to the development and persistence of a cicatrizing ulcerative proctitis resulting from poor blood supply to this area (Wilcock \& Olander 1977b, Brown et al. 2007, Gelberg 2007). While ulceration and necrosis occur, there is an intensive hyperplasia of fibroblasts from resident fibrocytes that begins to form a matrix, composed of mucopolysaccharides and collagen (Kumar et al. 2005). This dense maturing scar fibrosis, resulting from the repair process, promotes a decrease in the rectal lumen and partial occlusion (Lillie et al. 1973, Wilcock \& Olander 1977b, Kumar et al. 2005, Brown et al. 2007). The rectal portion of the intestine is the most susceptible to this kind of change due to poor vascular irrigation by blood at the junction of the circulatory fields of the caudal mesenteric and pudendal arteries (Wilcock \& Olander 1977b, Brown et al. 2007). Fibrinous thrombi can be found in rectal arterioles that provide ischemic necrosis in the mucosa and submucosa. In the cases reported herein, it is probable that $S$. Typhimurium was the causative agent of the necrotic enterocolitis observed as intense positive staining in the colon and rectum in the immunohistochemical study; therefore, the rectal stricture is attributed to a complication of this persistent infection.

The affected herd had previously suffered cases of Salmonella infection, indicating that this is not a naïve population for Salmonella serotypes, mainly S. Typhimurium which is the serotype most prevalent in enterocolitis cases in southern Brazil (Kich 2007). It is possible that PCV2 may have triggered (Segalés et al. 2004) salmonellosis enterocolitis in the reported cases because it can cause a concurrent enteric and debilitating disease. Cases of necrotic enterocolitis with PCV2 and S. Typhimurium coinfection have been previously reported (Zlotowski et al. 2009). However, cases of rectal stenosis resulting from Salmonella and PCV2 co-infection have not previously been reported.

One pig tested was negative to PCV2 immunohistochemical procedure. This finding could indicate a subclinical infection or a recovery phase of the disease (Segalés 2002) in which the amount of virus in the tissue is too low to allow PCV2 immunostaining. In this regard, it has been reported that a viral load of greater than $10^{8} \mathrm{PCV} 2$ genomes per 500ng DNA is required to give visible staining in the IHC (Brunborg et al. et al. 2004).

In intestinal tissues PCV2 is found in Peyer's patches associated with lymphoid depletion and hystiocytic replacement in the follicular centers as well in enterocytes and vascular endothelial cells (Segalés et al. 2004, Zlotowski et al. 2008). Also, depletion of goblet cells in the large intestine of PCV2-affected pigs has been reported, suggesting that the virus may interfere with the intestinal defense system via more than one mechanism (Zlotowski et al. 2008). Although the exact mechanism of interaction between Salmonella and PCV2 has not been defined, the presence of PCV2 in a herd may decrease the dose of the bacteria necessary to cause disease and increase the shedding by carrier pigs, probably because of the lymphoid depletion and the disruption of the intestinal defense system caused by the virus infection.

After the definitive diagnosis of salmonellosis was obtained, the outbreak was controlled by antimicrobial treatment. It was based on the sensitivity test, which reveals no microbial resistance to Enrofloxacin, the antimicrobial used by the veterinarian of the herd. According to the owner of the farm, the occurrence of cases of clinical diseases was considerably reduced after the implementation of the PCV2 vaccination program, suggesting that PCV2 was a facilitating factor associated with salmonellosis enteritis and that rectal stenosis is a consequence of salmonellosis infection.

Acknowledgements.- To Dália dos Prazeres Rodrigues, "Fundação Oswaldo Cruz", for the strain characterization of Salmonella. This study was supported by Grants from Coordenação de Aperfeiçoamento de Pessoal e Nível Superior (CAPES) and Conselho Nacional de Desenvolvimento Científico e Tecnológico (CNPq), Brazil.

\section{REFERENCES}

Brown C.C., Baker D.C. \& Barker I.K. 2007. Alimentary system, p.193199. In: Maxie M.G. (Ed.), Jubb, Kennedy \& Palmers Pathology of Domestic Animals. Vol.2. $5^{\text {th }}$ ed. W.B. Saunders, Philadelphia.

Brunborg I. M., Moldal T. \& Jonassen C.M. 2004. Quantitation of porcine circovirus type 2 isolated from serum/plasma and tissue samples of 
healthy pigs and pigs with postweaning multisystemic wasting syndrome using a TaqMan-based real-time PCR. J. Virol. Meth. 122:171-178.

Gelberg H.B. 2007. Alimentary system, p.363-365. In: McGavin M.D. \& Zachary J.F. (Eds), Pathologic Basis of Veterinary Disease. $4^{\text {th }}$ ed. Mosby, Philadelphia.

Griffith R.W., Schwartz K.J. \& Meyerholz D.K. 2006. Salmonella, p.739754. In: Straw B.E., Zimmerman J.J., D’Allaire S. \& Taylor D.J. (Eds), Diseases of Swine. $9^{\text {th }}$ ed. Blackwell, lowa.

Ha Y., Jung K., Kim J., Choi C. \& Chae C. 2005. Outbreak of salmonellosis in pigs with postweaning multisystemic wasting syndrome. Vet. Rec. 156:583-584.

Kich J.D. 2007. Salmonelose, p.197-203. In: Sobestiansky J. \& Barcellos D.E.S.N. (Eds), Doença dos Suínos. Cânone Editorial, Goiânia.

Kumar V., Abbas A.K. \& Fausto N. 2005. Tissue renewal and repair: Regeneration, healing, and fibrosis, p.87-118. In: Kumar V., Abbas A.K. \& Fausto N. (Eds), Robbins and Cotran Pathologic Basis of Disease. $7^{\text {th }}$ ed. Elsevier Saunders, Philadelphia. 1225p.

Lillie L.E., Olander H.J. \& Gallina A.M. 1973. Rectal stricture of swine. J. Am. Vet. Med. Assoc. 163(4):358-361.

Perfumo C.J., Sanguinetti H.R., Giorgio N., Armocida A.D., Machuca M.A., Massone A.R., Risso M.A., Aguirre J.I. \& Idiart J.R. 2002. Rectal stricture of postmortem examined pigs in a farrow-to-finishing unit: Considerations about the prevalence, pathology, etiology and pathogenesis. Arch. Med. Vet. 34(2):245-252.

Santos R.L., Raffatellu M., Bevins C.L., Adams L.G., Tü Kel C.., Tsolis R.M. \& Bäumler A.J. 2009. Life in the inflamed intestine, Salmonella style. Trends Microbiol. 17:498-506.

Schauser K., Olsen J.E. \& Larsson L.I. 2004. Immunocytochemical studies of Salmonella Typhimurium invasion of porcine jejunal epithelial cells. J. Med. Microbiol. 53:691-695.
Schwarz P., Kich J.D., Coldebella A., Seyboth L., Romeiro C., Corbellini L.G. \& Cardoso M. 2010. Frequência de suínos soropositivos para Salmonella sp. em granjas afetadas em diferentes níveis de severidade pela Síndrome Multissistêmica de Definhamento do Leitão Desmamado. Acta Sci. Vet. 38:127-132.

Segalés J. 2002. Update on postweaning multisystemic wasting syndrome and porcine dermatitis and nephropathy syndrome diagnostic. J. Swine HIth Prod. 10:277-281.

Segalés J., Domingo M., Chianini F., Majó N., Domínguez J., Darwich L. \& Mateu E. 2004. Immunosuppression in postweaning multisystemic wasting syndrome affected pigs. Vet. Microbiol. 98:151-158.

Seol M.S., Hur B.H., Matsuda K., Lim C.W. \& Song H.J. 2001. Rectal stricture in a finishing swine. Korean J. Vet. Serv. 24:375-377.

Sorden S.D., Harms P.A., Nawagitgul P., Cavanaugh D. \& Paul P.S. 1999. Development of a polyclonal-antibody-based immunohistochemical method for the detection of type 2 porcine circovirus in formalin-fixed, paraffin-embedded tissue. J. Vet. Diagn. Invest. 11:528530.

Wilcock B.P. \& Olander H.J. 1977a. The pathogenesis of porcine rectal stricture. I The naturally occurring disease and its association with salmonellosis. Vet. Pathol. 14:36-42.

Wilcock B.P. \& Olander H.J. 1977b. The pathogenesis of porcine rectal stricture- II. Experimental salmonellosis and ischemic proctitis. Vet. Pathol. 14:43-55.

Zlotowski P., Corrêa A.M.R., Barcellos D.E.S.N., Cardoso M.R.I., Vasconcelos A.C., Castro L.A. \& Driemeier D. 2009. Necrotic enterocolitis in pigs naturally infected by porcine circovirus type 2 . Ciência Rural 39:1801-1807.

Zlotowski P., Corrêa A.M.R., Barcellos D.E.S.N., Cruz C.E.F., Asanome W., Barry A.F., Alfieri A.A. \& Driemeier D. 2008. Intestinal lesions in pigs affected with postweaning multisystemic wasting syndrome. Pesq.Vet. Bras. 28:313-318. 